\title{
R-factor Mediated Dihydrofolate Reductases which Confer Trimethoprim Resistance
}

\author{
By S. G. B. AMYES* AND J. T. SMITH \\ Microbiology Section, Department of Pharmaceutics, \\ The School of Pharmacy, University of London, \\ 29/39 Brunswick Square, London WC1N $1 A X$
}

(Received 1 March 1978)

\begin{abstract}
Six different $\mathrm{R}$-factors conferring trimethoprim resistance had been isolated from a variety of sources. The trimethoprim-resistant dihydrofolate reductases (EC 1.5.1.3) from strains containing these R-factors were purified by ammonium sulphate precipitation and DEAEcellulose ion-exchange chromatography. The enzymes showed no significant differences in molecular weight, $\mathrm{pH}$ profile, substrate profile, heat sensitivity, inhibition profile and Michaelis-Menten kinetics. There was, however, considerable variation in the specific activity of these enzymes in the same bacterial host. When two Escherichia coli trimethoprimsensitive dihydrofolate reductases were examined as controls, considerable differences between their properties and those of the enzymes mediated by R-factors were detected. The data suggest that one trimethoprim resistance gene could be spreading through the bacterial population, possibly situated on a transposon.
\end{abstract}

\section{INTRODUCTION}

Shortly after the introduction of trimethoprim in the United Kingdom, bacterial strains harbouring $\mathrm{R}$-factors which conferred resistance to this drug appeared in clinical isolates from London hospitals (Fleming et al., 1972). The first R-factor of this type was designated R388 and conferred trimethoprim resistance by coding for an additional target enzyme, dihydrofolate reductase (5,6,7,8-tetrahydrofolate:NADP ${ }^{+}$oxidoreductase; EC 1.5.1.3), which is very much less susceptible to the drug than the host enzyme (Amyes \& Smith, 1974). Indeed, the R-factor enzyme had many other different properties when compared with the host enzyme (Amyes \& Smith, 1976).

Since the isolation of R388, a number of different R-factors conferring trimethoprim resistance have been isolated. One such plasmid, R483, contains a 'transposon' conferring trimethoprim and streptomycin resistance (Barth et al., 1976). Subsequent reports have suggested that other trimethoprim resistance genes may also be on transposons (Barth \& Datta, 1977).

In this paper, we compare the properties of the dihydrofolate reductases mediated by a variety of $\mathrm{R}$-factors which confer trimethoprim resistance. Within experimental variation, it would seem that all the enzymes have originated from a common determinant and the implications of these findings are discussed.

* Present address: Department of Bacteriology, The Medical School, University of Edinburgh, Teviot Place, Edinburgh EH8 9AG. 
Table 1. Bacterial strains and $R$-factors

\begin{tabular}{|c|c|c|}
\hline Bacteria & & \\
\hline Strain & Characteristics & Source \\
\hline $\begin{array}{l}\text { Escherichia coli } 114 \\
\text { E. coli } \mathrm{3} 6-2\end{array}$ & $\begin{array}{l}\text { prototroph, } \mathrm{F}^{-} \\
\text {pro trp his, } \mathrm{F}^{-}\end{array}$ & $\begin{array}{l}\text { Obtained from Professor K. Simpson } \\
\text { K12 strain (Clowes \& Rowley, 1954) }\end{array}$ \\
\hline
\end{tabular}

R-plasmids

Plasmid

R388

R483

R721

R751

Rss28

Rss42

\begin{tabular}{lc} 
& Incompatibility \\
\multicolumn{1}{c}{ Resistances* } & group \\
$\mathrm{TmSx}$ & IncW \\
$\mathrm{TmSm} / \mathrm{Sp}$ & IncI $\alpha$
\end{tabular}

IncI $\delta$

IncP

IncP

IncI $\alpha$

* Tm, Trimethoprim resistance; $\mathrm{Sm} / \mathrm{Sp}$, streptomycin/spectinomycin resistance via streptomycin adenylation; Sm, streptomycin resistance only via streptomycin phosphorylation; Sx, sulphonamide (sulphamethoxazole) resistance.

\section{METHODS}

Bacterial strains and $R$-factors. Strains and plasmids used are listed in Table 1.

Materials. NADPH was purchased from P.L. Biochemicals (Milwaukee, Wisconsin, U.S.A.), dihydrofolate from Sigma, DEAE-cellulose from Whatman and Sephadex G-75 from Pharmacia. Trimethoprim was kindly given by the Wellcome Research Laboratories and amethopterin by Lederle Laboratories.

Enzyme preparation. Cultures (50 l) in minimal medium (Davis \& Mingioli, 1950) with $0.28 \%(\mathrm{w} / \mathrm{v})$ glucose as carbon source were grown aerobically to the late-exponential phase. The bacteria were harvested by centrifugation, washed twice in growth medium lacking glucose and resuspended in 0.01 vol. $50 \mathrm{~mm}$ -

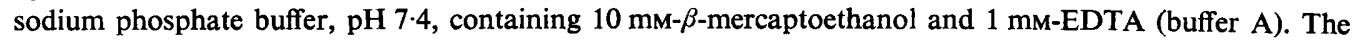
bacteria were disrupted ultrasonically and centrifuged at $38000 \mathrm{~g}$ for $1 \mathrm{~h}$ as previously described (Amyes \& Smith, 1976). The specific activity of dihydrofolate reductase in the supernatant was estimated. The two dihydrofolate reductases, one sensitive to trimethoprim (host enzyme) and the other resistant (R-factor enzyme), were separated by ammonium sulphate precipitation and DEAE-cellulose ion-exchange chromatography as described before (Amyes \& Smith, 1976).

Molecular weight determinations. Molecular weights were determined using Sephadex exclusion chromatography as described previously (Amyes \& Smith, 1974) with ovalbumin, chymotrypsinogen and cytochrome $c$ as markers.

Protein estimation. All protein concentrations were estimated by the method of Waddell (1956).

Heat sensitivity. The enzyme preparation was maintained at $45^{\circ} \mathrm{C}$ in buffer $\mathrm{A}$ in a prewarmed container. After the requisite time, the sample was cooled in ice and the enzyme activity was assayed in the usual manner.

Dihydrofolate reductase assay. Dihydrofolate reductase activity was assayed by the method of Osborn \& Huennekens (1958) as described previously (Amyes \& Smith, 1974).

\section{RESULTS}

\section{Specific activity}

Six plasmids conferring trimethoprim resistance were transferred into Escherichia coli strain 114. Five of the plasmids, which were apparently all different from one another, came from London hospitals and the sixth from Frant in Kent (Table 1). The specific dihydrofolate reductase activities in $E$. coli 114 harbouring these R-factors were measured at $\mathrm{pH} 6.0$ in phosphate buffer at $30^{\circ} \mathrm{C}$ before any separation of trimethoprim-sensitive and trimethoprim-resistant enzymes was attempted.

As found previously (Amyes \& Smith, 1974), the presence of the R388 dihydrofolate reductase in crude enzyme extracts did not significantly affect the specific activity of 
Table 2. Specific dihydrofolate reductase activities in cell extracts of $E$. coli 114 and its $R^{+}$derivatives

Specific activities are expressed as nmol dihydrofolate reduced $\min ^{-1}$ (mg protein $)^{-1}$. Relative activities are given relative to the activity in extracts of $E$. coli 114.

Organism

E. coli 114

E. coli $\mathrm{j6-2}$

E. coli 114(R388)

E. coli $114(\mathrm{R} 483)$

E. coli 114(R721)

E. coli 114(R751)

E. coli $114(\mathrm{Rss} 28)$

E. coli 114(Rss42)
Specific activity

$1 \cdot 35$
$1 \cdot 35$
$1 \cdot 48$
$13 \cdot 90$
$4 \cdot 32$
$1 \cdot 34$
$1 \cdot 21$
$14 \cdot 44$

Relative activity

$1 \cdot 00$
$1 \cdot 00$
$1 \cdot 10$
$10 \cdot 29$
$3 \cdot 20$
$0 \cdot 99$
0.90
$10 \cdot 70$

dihydrofolate reductase in E. coli 114 (Table 2). However, the presence of R483 and Rss42 increased the level of dihydrofolate reductase about 10 -fold compared with the $R^{-}$strain. Of the other three R-factors, R751 and Rss28 did not affect the specific activity of dihydrofolate reductase in crude extracts, while $R 721$ increased it threefold compared with the $\mathrm{R}^{-}$strain. When these plasmids were transferred into $E$. coli strain $\mathrm{J6}-2$ the specific activities of the cell extracts were similar to those found in E. coli 114.

\section{Separation by ion-exchange chromatography}

Ammonium sulphate was added to crude enzyme extracts from 501 late-exponential phase cultures of each $\mathrm{R}^{+}$strain to $50 \%$ saturation to precipitate NADPH oxidase activity. There was no significant level of dihydrofolate reductase activity in the precipitate. Ammonium sulphate was added to the supernatant to $80 \%$ saturation. The resulting precipitate was resuspended in a minimum volume (about $50 \mathrm{ml}$ ) of $10 \mathrm{~mm}$-Tris $/ \mathrm{HCl}$ buffer, pH 8.5, containing $10 \mathrm{~mm}-\beta$-mercaptoethanol and $1 \mathrm{~mm}$-EDTA (buffer B) and dialysed against $100 \mathrm{vol}$. of similar buffer. The contents of each dialysis sac were applied to a DEAE-cellulose column $\left(2 \mathrm{~cm}^{2} \times 30 \mathrm{~cm}\right)$ pre-equilibrated with buffer B. Buffer B was passed downwards through the column and the effluent was monitored at $280 \mathrm{~nm}$. When the absorbance dropped below 0.08 units, the buffer was changed to a linear gradient of 0 to $1.0 \mathrm{M}$-sodium chloride in buffer B $(800 \mathrm{ml})$. Fractions of $10 \mathrm{ml}$ were collected and assayed for dihydrofolate reductase activity in the presence and absence of $4 \mu \mathrm{M}$ trimethoprim, and for protein by the method of Waddell (1956).

The $\mathrm{R}^{-}$strains $E$. coli 114 and $E$. coli $\mathrm{J} 6-2$ showed a single peak of dihydrofolate reductase activity (Fig. $1 a, b$ ). Both peaks eluted at $0.38 \mathrm{M}$-sodium chloride. When the ammonium sulphate precipitate from $E$. coli $114(\mathrm{R} 388)$ was applied to the column, there was a small peak of trimethoprim-resistant dihydrofolate reductase activity 25 fractions earlier than the trimethoprim-sensitive dihydrofolate reductase peak of the host cell (Fig. 1c). This peak eluted at $0 \cdot 1 \mathrm{M}$-sodium chloride. When the activities represented by each peak were summed, the activity of the R-factor enzyme was about $18 \%$ of the host activity. The extract from $E$. coli 114 (R483) produced a trimethoprim-resistant enzyme peak about 9.5 times larger than that of the host cell, in the same relative position as that from R388 (Fig. 1d), i.e. eluting at $0 \cdot 1 \mathrm{M}$-sodium chloride. The extracts obtained from the other four $\mathrm{R}^{+}$strains each showed a trimethoprim-resistant enzyme peak at a similar position in addition to the trimethoprim-sensitive host cell enzyme peak (Fig. $1 e$ to $h$ ). The only difference between the extracts from these $\mathrm{R}^{+}$strains was the size of the trimethoprim-resistant enzyme peak, e.g. R483 and Rss42 had about 200 times as much trimethoprim-resistant enzyme as R751. 


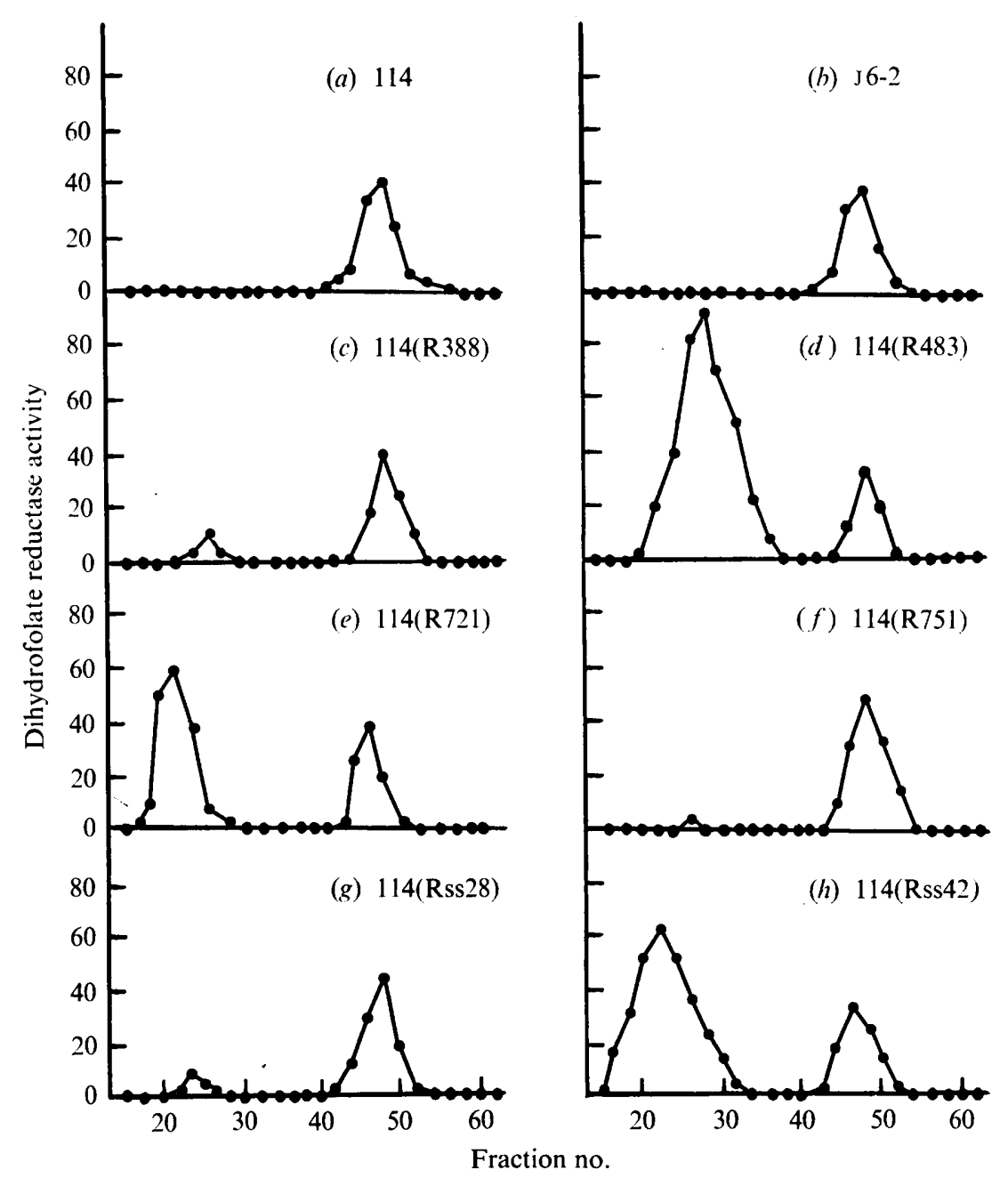

Fig. 1. Dihydrofolate reductase activities (expressed as nmol dihydrofolate $\mathrm{min}^{-1} \mathrm{ml}^{-1}$ ) in fractions obtained after DEAE-cellulose ion-exchange chromatography for the two trimethoprim-sensitive $E$. coli strains and the six strains harbouring $\mathrm{R}$-factors.

\section{pH profile}

The $\mathrm{pH}$ profiles of all the R-factor mediated trimethoprim-resistant dihydrofolate reductases and the two $E$. coli trimethoprim-sensitive enzymes were compared using DEAE-cellulose purified material. The $E$. coli trimethoprim-sensitive enzymes differed from each other (Fig. 2). The enzyme from strain J6-2 had a discontinuous pattern with the three different buffers whereas the results with strain 114 nearly fitted into one curve. The type of behaviour seen with strain $\mathrm{J6-2}$ has been noted before in other $E$. coli strains (Mathews \& Sutherland, 1965). However, both E. coli enzymes showed a broad spectrum of activity over almost the complete $\mathrm{pH}$ range tested and this is common to most bacterial dihydrofolate reductases. On the other hand, all six of the R-factor enzymes exhibited a sharp peak at $\mathrm{pH} 6.0$ in phosphate buffer, with $95 \%$ activity over only about $0.4 \mathrm{pH}$ units (Fig. 2). 


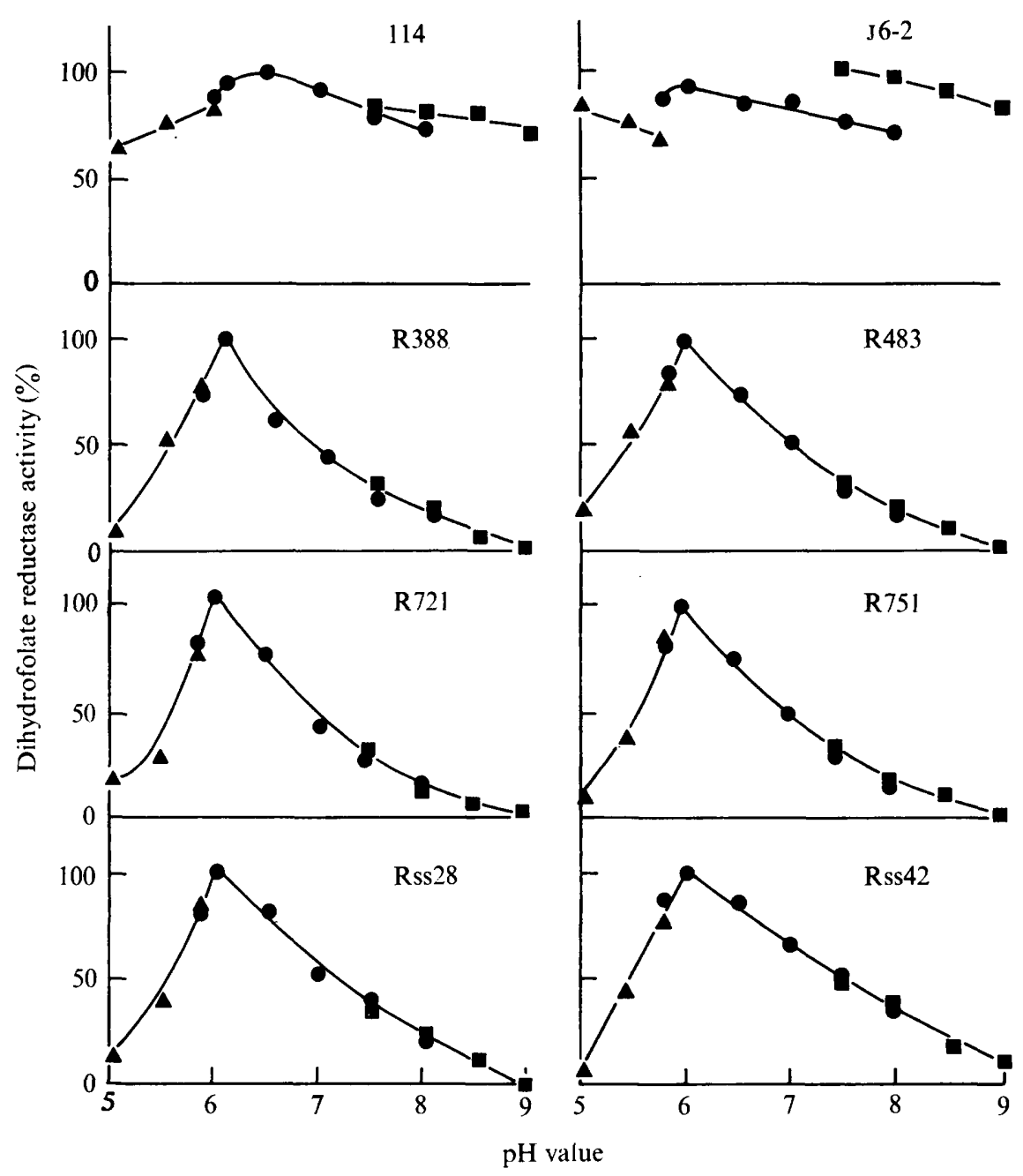

Fig. 2. Percentages of maximum dihydrofolate reductase activities at different pH values for the trimethoprim-sensitive enzymes from $E$. coli 114 and $\mathrm{j6-2}$ and the trimethoprim-resistant enzymes from the $\mathrm{R}^{+}$strains. Sodium acetate buffer was used for the range pH $5 \cdot 0$ to $5 \cdot 7(\Delta)$, sodium phosphate buffer for the range pH $5 \cdot 7$ to $8.0(\mathcal{O})$ and Tris/ $\mathrm{HCl}$ buffer for the range pH $7 \cdot 5$ to $9 \cdot 0$ : each buffer was used at $40 \mathrm{~mm}$.

\section{Molecular weight}

Ammonium sulphate (50 to $80 \%$ saturation) samples were applied to a Sephadex G-75 gel filtration column $\left(4 \mathrm{~cm}^{2} \times 60 \mathrm{~cm}\right)$ and eluted with buffer A (Amyes \& Smith, 1974; Andrews, 1964). The J6-2 dihydrofolate reductase had a molecular weight of 20500 (Table 3) similar to that of the enzyme from E. coli 114 (Amyes \& Smith, 1974). The R388 enzyme had a molecular weight of 35000 (Amyes \& Smith, 1974) similar to that of the other five R-factor enzymes.

\section{Substrate profile and heat sensitivity}

A feature which distinguishes the R388 enzyme from the host enzyme of $E$. coli 114 is their different substrate specificity profiles. With the trimethoprim-sensitive $E$. coli 114 dihydrofolate reductase, about $16 \%$ of the activity seen with NADPH was observed when NADH was used instead (Amyes \& Smith, 1976). Similarly, the J6-2 enzyme exhibited $8.2 \%$ of the NADPH activity when NADH was used. However, in DEAE-cellulose 
Table 3. Molecular weights of dihydrofolate reductases

Source of enzyme
E. coli 114
E. coli $\mathrm{J6}-2$
R388
R483
R721
R751
Rss28
Rss42

Molecular weight 21000 20500 35000 33500 33000 34000 33000 33000

Table 4. Time taken to lose $50 \%$ dihydrofolate reductase activity at $45^{\circ} \mathrm{C}$

$\begin{array}{lc}\text { Source of enzyme } & \text { Time (min) } \\ \text { E. coli } 114 & 15 \cdot 0 \\ \text { E. coli } \mathrm{J6}-2 & 12 \cdot 2 \\ \text { R388 } & 2 \cdot 0 \\ \text { R483 } & 1 \cdot 5 \\ \text { R721 } & 2 \cdot 3 \\ \text { R751 } & 2 \cdot 1 \\ \text { Rss } 28 & 2 \cdot 5 \\ \text { Rss } 42 & 2 \cdot 2\end{array}$

Table 5. Trimethoprim and amethopterin concentrations which cause $50 \%$ inhibition of dihydrofolate reductase activities

Each dihydrofolate reductase was assayed in $40 \mathrm{~mm}$-sodium phosphate buffer, $\mathrm{pH} 6.0$, in the absence and presence of increasing concentrations of trimethoprim or amethopterin.

$\begin{array}{lcc}\text { Source of enzyme } & \begin{array}{c}\text { Trimethoprim } \\ \text { (M) }\end{array} & \begin{array}{c}\text { Amethopterin } \\ \text { (M) }\end{array} \\ \text { E. coli } 114 & 1.0 \times 10^{-8} & 2.5 \times 10^{-9} \\ \text { E. coli } \mathrm{J6-2} & 1.1 \times 10^{-8} & 1.4 \times 10^{-8} \\ \text { R388 } & 1.8 \times 10^{-4} & 7.5 \times 10^{-6} \\ \text { R483 } & 1.5 \times 10^{-4} & 8.0 \times 10^{-6} \\ \text { R721 } & 4.0 \times 10^{-4} & 9.0 \times 10^{-6} \\ \text { R751 } & 1.2 \times 10^{-4} & 5.0 \times 10^{-6} \\ \text { Rss28 } & 1.9 \times 10^{-4} & 6.5 \times 10^{-6} \\ \text { Rss42 } & 2.0 \times 10^{-4} & 2.0 \times 10^{-6}\end{array}$

purified preparations of all the R-factor mediated enzymes, there was no detectable activity when NADH was substituted for NADPH. None of the eight enzymes exhibited any activity when folic acid was substituted for dihydrofolic acid.

The heat sensitivity of each DEAE-cellulose purified enzyme preparation was measured (Table 4). Both the E. coli J6-2 and 114 enzymes were relatively stable on heating to $45^{\circ} \mathrm{C}$, each losing half its activity in about $15 \mathrm{~min}$. The R-factor enzymes were less stable at this temperature, all of them losing $50 \%$ activity after about $2 \mathrm{~min}$.

\section{Inhibition of dihydrofolate reductase}

The most notable feature of the R388 enzyme, which led to its discovery, is its very high level of resistance to trimethoprim. In order to compare the new R-factor determined enzymes, the extent of their resistance to trimethoprim was determined using DEAEcellulose purified preparations. They were assayed in increasing concentrations of trimethoprim at $\mathrm{pH} 6.0$ (the $\mathrm{pH}$ optimum) and the concentration required to give $50 \%$ inhibition $\left(\mathrm{ID}_{50}\right)$ of each enzyme was determined (Table 5). The $\mathrm{J6}-2$ enzyme was as susceptible to trimethoprim as the 114 dihydrofolate reductase, each being inhibited by 
Table 6. Michaelis-Menten kinetics of dihydrofolate reductases with dihydrofolate as substrate and trimethoprim as inhibitor

$\begin{array}{lcc}\text { Source of enzyme } & \begin{array}{c}K_{\mathrm{m}} \text { for } \\ \text { dihydrofolate } \\ (\mathrm{M})\end{array} & \begin{array}{c}K_{\mathrm{j}} \text { for } \\ \text { trimethoprim } \\ (\mathrm{M})\end{array} \\ \text { E. coli } 114 & 2.0 \times 10^{-5} & 6.0 \times 10^{-9} \\ \text { E. coli } \mathrm{J6-2} & 1 \cdot 7 \times 10^{-5} & 2.7 \times 10^{-9} \\ \text { R388 } & 8.3 \times 10^{-6} & 1.5 \times 10^{-4} \\ \text { R483 } & 2.0 \times 10^{-6} & 3.2 \times 10^{-5} \\ \text { R721 } & 2.5 \times 10^{-6} & 7.6 \times 10^{-5} \\ \text { R751 } & 4.2 \times 10^{-6} & 4.5 \times 10^{-5} \\ \text { Rss28 } & 5.0 \times 10^{-6} & 3.0 \times 10^{-5} \\ \text { Rs542 } & 1.0 \times 10^{-6} & 3.6 \times 10^{-5}\end{array}$

$50 \%$ by about $10 \mathrm{~nm}$ of drug. The R-factor enzymes were all considerably more resistant to trimethoprim with little variation between them (Table 5). On average, the $\mathrm{R}$-factor enzymes were 20000 times less susceptible to trimethoprim than the dihydrofolate reductases from their $E$. coli hosts.

The activity of all these enzymes was also assayed at $\mathrm{pH} 6.0$ in the presence of increasing concentrations of amethopterin. The $E$. coli 114 and $\mathrm{J6}-2$ enzymes had ID $_{50}$ values of about 2 nM-amethopterin (Table 5). There was little variation in the $\mathrm{ID}_{50}$ of amethopterin for each of the R-factor enzymes tested. On average, they were about 3000 times more resistant than the bacterial enzymes.

\section{Michaelis-Menten kinetics}

Using Michaelis-Menten kinetics we have shown previously that the affinity for dihydrofolate is higher with the R388 enzyme than with the E. coli 114 enzyme (Amyes \& Smith, 1976). DEAE-cellulose purified preparations of each of the R-factor mediated enzymes were assayed in decreasing concentrations of dihydrofolate and $K_{\mathrm{m}}$ values were estimated from double reciprocal plots of activity versus substrate concentration (Table 6). The R-factor enzymes all exhibited lower $K_{\mathrm{m}}$ values than those of the two host enzymes. There was some variation between the R-factor enzymes but these differences were probably not significant.

Assays of the R-factor enzymes in the presence of different concentrations of dihydrofolate were repeated in the presence of trimethoprim. As had been found with the R388 enzyme, the presence of trimethoprim did not alter the maximum velocity of reduction of dihydrofolate by any of the R-factor enzymes tested. This shows that each R-factor enzyme, like the enzymes of $E$. coli 114 and $E$. coli $\mathrm{J} 6-2$, was competitively inhibited by trimethoprim, although in the case of the R-factor enzymes, much more trimethoprim was needed. The inhibitor constants (see Dixon \& Webb, 1958) are shown in Table 6. The small variations between the inhibitor constants of the $\mathrm{R}$-factor enzymes are probably not significant because of the low levels of activity being tested. Each of the R-factor mediated enzymes had an inhibitor constant for trimethoprim about 10000 to 20000 times greater than that of either of the trimethoprim-sensitive host enzymes.

\section{Minimum inhibitory concentration}

We have found no characteristics which distinguish between the R-factor mediated enzymes except that they are produced in differing quantities. It might be expected that these differences would be reflected in the level of resistance shown by each $\mathrm{R}^{+}$strain. Therefore about 50 viable organisms were plated on minimal medium agar plates containing increasing concentrations of trimethoprim. After $3 \mathrm{~h}$ incubation the lowest concentration of trimethoprim giving no visible growth was taken as the minimum inhibitory 


\section{Table 7. Antibacterial effect of trimethoprim and comparative levels of $R$-factor determined dihydrofolate reductases}

Minimum inhibitory concentrations are expressed as $\mu \mathrm{g}$ trimethoprim $\mathrm{ml}^{-\mathbf{1}}$. The levels of $\mathbf{R}$-factor mediated dihydrofolate reductases are given as a percentage of the level of $E$. coli 114 dihydrofolate reductase (data from Fig. 1).

$\begin{array}{lcc}\text { Organism } & \begin{array}{c}\text { Minimum inhibitory } \\ \text { concentration }\end{array} & \begin{array}{c}\text { dihydrofolate } \\ \text { reductase } \\ (\%)\end{array} \\ \text { E. coli } 114 & 0 \cdot 2 & - \\ \text { E. coli } \text { J6-2 } & 0 \cdot 4 & - \\ \text { E. coli } 114(\mathrm{R} 388) & 2000 & 18 \\ \text { E. coli } 114(\mathrm{R} 483) & 1800 & 645 \\ \text { E. coli } 114(\mathrm{R} 721) & 1800 & 213 \\ E . \text { coli } 114(\mathrm{R} 751) & 1800 & 4 \\ \text { E. coli } 114(\mathrm{Rss} 28) & 2000 & 17 \\ \text { E. coli } 114(\mathrm{Rss42)} & 2000 & 477\end{array}$

concentration. The minimum inhibitory concentrations for the $\mathrm{R}^{+}$strains varied little from one to another (Table 7). Thus the widely varying levels of trimethoprim-resistant dihydrofolate reductase did not appear to cause any difference in resistance level. This is a surprising result since Breeze et al. (1975) found that enzyme levels varying by only 30-fold significantly alter the resistance of $E$. coli to trimethoprim. However, Jackson \& Harrap (1973) have shown that some mammalian cells grow normally when only $5 \%$ of their normal dihydrofolate reductase level is functional. It would seem that the R-factor enzymes studied here confer a level of resistance on the host which depends only on the extent of the insensitivity of the plasmid mediated dihydrofolate reductase to trimethoprim.

\section{DISCUSSION}

Each of the six R-factors studied here codes for an additional dihydrofolate reductase that is much less susceptible to the action of trimethoprim than the host $E$. coli enzyme. The degree to which these enzymes are susceptible, as measured by inhibitor constants and ID $_{50}$ estimations, nearly matches the increase in minimum inhibitory concentration of the $\mathrm{R}^{+}$strains. Therefore, as with $\mathrm{R} 388$, the mechanism of resistance in each case is due to the production of a plasmid-coded enzyme.

One of the most striking differences between the $E$. coli 114 dihydrofolate reductase and the R388 enzyme was the effect of pH on enzyme activity (Amyes \& Smith, 1976). The enzymes mediated by each $\mathrm{R}$-factor that conferred trimethoprim resistance had the same characteristics as the $\mathrm{R} 388$ enzyme. No $\mathrm{pH}$ profile of dihydrofolate reductase from any other source resembles those of the R-factor enzymes (Burchall \& Hitchings, 1965; Mathews \& Sutherland, 1965). The pH profile showed a clear distinction between the two $E$. coli trimethoprim-sensitive enzymes, but did not separate any of the R-factor enzymes.

Taking the physical properties as a whole, there seems a remarkable resemblance between the R-factor enzymes. If they are not the same enzyme, they are very similar. These $\mathrm{R}$-factors were from a variety of sources, only two coming from the same hospital. If these enzymes are identical then the same structural gene must be present on each plasmid. This could be compared to the TEM $\beta$-lactamase gene, which is widespread among R-factors (Hedges et al., 1974). Hedges et al. (1974) concluded that the structural gene for the TEM-like enzyme was ubiquitous because of its ability to translocate from replicon to replicon. This was later confirmed as the TEM $\beta$-lactamase was shown to reside on a transposon which could be rapidly transmitted through populations of bacteria and their R-factors (Hedges \& Jacob, 1974). 
Two of the R-factors studied here, R483 and R721, contain another transposon (Tn7) conferring trimethoprim and streptomycin resistance (Barth et al., 1976; Barth \& Datta, 1977). R751 also contains a trimethoprim resistance gene that can translocate from one replicon to another, and this has been termed Tn402 (Shapiro \& Sporn, 1977). Preliminary evidence suggests that the trimethoprim resistance gene of R388 may also be on a transposon (Amyes \& Smith, 1977). It has not yet been proved whether Rss28 and Rss42 contain transposons. However, both contain the gene for streptomycin/spectinomycin resistance and this resistance, in combination with trimethoprim resistance, has been associated with transposon 7 (Barth \& Datta, 1977).

The close enzymic similarity between these $\mathrm{R}$-factor dihydrofolate reductases is apparently contradicted by the large variations in enzyme levels. Why there is such a variation is unknown. It seems unlikely that the high levels of activity could be explained by gene amplification, because R483 has been shown to exist as only one copy per cell (Barth et al., 1976) and yet this $\mathrm{R}$-factor confers one of the highest specific activities. If the structural genes for these enzymes are transposable, it may be that both the site and direction of insertion into other replicons could be the factor responsible for different levels of gene transcription.

\section{REFERENCES}

Amyes, S. G. B. \& Sмith, J. T. (1974). R-factor trimethoprim resistance: an insusceptible target site. Biochemical and Biophysical Research Communications 58, 412-418.

Amyes, S. G. B. \& SмIтH, J. T. (1976). The purification and properties of the trimethoprimresistant dihydrofolate reductase mediated by the $\mathrm{R}$-factor, R388. European Journal of Biochemistry 61, 597-603.

Amyes, S. G. B. \& SмIтH, J. T. (1977). Trimethoprim resistance controlled by a combination of plasmid and chromosomal genes. Genetical Research 29, 35-45.

ANDREwS, P. (1964). Estimation of the molecular weight of proteins by Sephadex gel filtration. Biochemical Journal 91, 222-233.

BARTh, P. T. \& DAtTA, N. (1977). Transposons determining trimethoprim and streptomycin resistance that are indistinguishable from transposon 7. Proceedings of the Society for General Microbiology 4, 99-100.

Barth, P. T., DAtTa, N., Hedges, R. W. \& Grinter, N. J. (1976). Transposition of a deoxyribonucleic acid sequence encoding trimethoprim and streptomycin resistance from $\mathrm{R} 483$ to other replicons. Journal of Bacteriology 125, 800-810.

Breeze, A. S., Sims, P. \& Stacey, K. A. (1975). Trimethoprim-resistant mutants of $E$. coli $\mathrm{k} 12$ : preliminary genetic mapping. Genetical Research 25, 207-214.

Burchall, J. J. \& Hitchings, G. H. (1965). Inhibitor binding analysis of dihydrofolate reductase from various species. Molecular Pharmacology 1, 126-136.

Clowes, R. C. \& Rowley, D. (1954). Some observations on linkage effects in genetic recombination in Escherichia coli $\mathrm{K} 12$. Journal of General Microbiology 11, 250-260.
Davis, B. D. \& Mingioli, E. S. (1950). Mutants of Escherichia coli requiring methionine or vitamin $\mathrm{B}_{12}$. Journal of Bacteriology 60, 17-28.

DixON, M. \& WEBB, E. C. (1958). Enzymes, 1st edn, pp. 8-34. London: Longmans.

Fleming, M. P., DatTa, N. \& Grüneberg, R. N. (1972). Trimethoprim resistance determined by R-factors. British Medical Journal i, 726-728.

Hedges, R. W. \& JACOB, A. E. (1974). Transposition of ampicillin resistance from RP4 to other replicons. Molecular and General Genetics 132, 31-40.

Hedges, R. W., Datta, N., Kontamichalou, P. \& SMITH, J. T. (1974). Molecular specificities of $\mathrm{R}$-factor-determined $\beta$-lactamases: correlation with plasmid compatibility. Journal of Bacteriology 117, 56-62.

JACKSON, R. C. \& HarRap, K. R. (1973). Studies with a mathematical model of folate metabolism. Archives of Biochemistry and Biophysics 158, 827-841.

Mathews, C. K. \& Sutherland, K. E. (1965). Comparative biochemistry of bacterial and phageinduced dihydrofolate reductases. Journal of Biological Chemistry 240, 2142-2147.

Osborn, M. J. \& HuENNEKENS, F. M. (1958). Enzymic reduction of dihydrofolic acid. Journal of Biological Chemistry 233, 969-974.

Shapiro, J. A. \& SPORN, P. (1977). Tn 402: a new transposable element determining trimethoprim resistance that inserts in bacteriophage Lambda. Journal of Bacteriology 129, 1632-1635.

WADDELL, W. J. (1956). A simple ultraviolet spectrophotometric method for the determination of protein. Journal of Laboratory and Clinical Medicine 48, 311-314. 